\title{
Towards integrated water resources management considering hydro-climatological scenarios: an option for sustainable development
}

\author{
Tesfa Worku Meshesha ${ }^{1 *}$ and Deepak Khare ${ }^{2}$
}

\begin{abstract}
Background: In the rainfed areas, water, not land, is the foremost restraining resources for better agricultural production to satisfy the growing demand of food and other needs. Water harvesting and enhancing productivity of available water, and not volume of yield per units of land, is therefore a better solution for rainfed agriculture. Under these circumstances, it is necessary toimplement efficient and effective integrated water resources management practices. Elsewhere rainfed dependent highland parts of Ethiopia, in the Beressa watershed most of the rainwater lost in the form of runoff particularly during excess rainfall; therefore, the benefit of rainwater during less rainy season is insignificant. The objective of this study therefore was to assess crop water requirement and net irrigation requirement using CROPWAT8.0 model and Rainfall Contribution Index (RCI) for various crops and to describe the benefits of water harvesting and integrated and sustainable water resources management. Crops growing during the month of February to June (less rainy season) are among the highest irrigation requirements.

Results: Based on $\mathrm{RCI}$ (as the value far from 1) reflect rainfall contribution is insufficient to satisfy the crop water requirements for the whole growth stages. Therefore, there is a need for supplemental irrigation and rainwater harvesting and a necessity for integrated water resources management. To reduce the intensity of water shortage therefore conservation planning and water management at watershed level in an integrated manner is critical. Similarly, soil and water conservation management practices is essential for the communities to reduce runoff and other resources for future uses and determine the optimal amount of water resources consumption at the irrigation fields is an urgent issues.
\end{abstract}

Conclusions: As a result, there is a need to do more efforts related to water harvesting and integrated water resources management for the sustainability of agriculture and over all human survival.

Keywords: CROPWAT8.0, RCI, IWRM, Water harvesting, Supplemental irrigation, Ethiopia

\section{Background}

Environment, water and land resources are the most fragile component of the earth. To secure the sustainability of adequate availability of water, sustainable food supply and public health, the interaction between these

\footnotetext{
*Correspondence: hopee2011@gmail.com;

tesfaworku.worku@gmail.com

${ }^{1}$ Department of Water Resources and Irrigation Management, Debre

Berhan University, P.o.BOX: 91, Addis Ababa, Ethiopia

Full list of author information is available at the end of the article
}

fragile resources have significant influence, therefore properly managed. Because the quality of people life is directly depending on how well these resources are conserved (Matondo 2002; Worku et al. 2018). In the development of human life, water has considerable contribution. During the ancient time human civilization has grew up along Euphrates and Tigris, Indus and Nile river valley. Even though it played a major role in the human endeavour, the planning and management of these resources was for single purpose only. Due to increase 
in competing interest over resources resulted from rapid population growth and higher demand for productivity, consequently multi-purpose water resources planning is emerged. In the previous, decades water resources planning and management is one-way (top-down) approach particularly in the developing countries. In this approach the people has no say on the issue related to planning and implementation of water resources project. Integrated water resources planning and management is considered as a participatory, technically as well as scientifically organized. Involvement in any activities of water resources project, stakeholders are the focal point in the integrated water resources planning and management approach. To address specific local issues the empowered local communities has responsibility in a coordinated and integrated way.

During the ancient periods, the plan of water related projects did not pay attention for the rest of the environment and hence resultant negative consequence to the environment. The environmental impact assessment therefore is vital parts of water resources planning and management. To satisfy goal and objectives of the society to present and for the future as well as preserving the integrity between environmental, ecological and hydrological system, sustainable water resources systems planning and management are designed (Loucks 2000). According to Simonovic (2000) and Wurbs (1998), however, for the future water resources related problems are drastically more complex. As can be seen in Fig. 1 alarming rate of population growth, social and environmental consideration, climatic variability, transboundary consideration and resources degradation are accelerate the complexity nature of water resources planning and management problems.

\section{Integrated water resources management and sustainable development}

Integrated water resources planning and management is one of the element of natural resources management, hence it has considered as one of the tools of environmental management (Fig. 2). The optimal, efficient use and management of water resource for the development of agricultural sector is one of the crucial parts of integrated water resources planning and management as of it integrates the development of water and land resources, and the development of economic and social aspects for the watershed. It used to coordinate and harmonize between human activities, which undertake in the watershed, and the conflicting interest among users through increasing the benefit obtain. Therefore, the concept and essence of integrated water resources planning and management in boosting productivity obtaining from agricultural and other sectors within the constraints, which imposed by the social, ecological, environmental and economical context of a certain watershed (Gorantiwar and Smout 2005; Gorantiwar et al. 2006).

According to Molden et al. (2003) and Halefom et al. (2017), demonstrated how water management at the field level, watershed level and irrigation system level can integrate in different ways to optimize the productivity of water. They advocated consideration related to principles of irrigation scheduling, which is an opportunity for communities using irrigation practice to cope with the natural resources pressure that has been put on them to utilize available water optimally and consideration to the downstream natural resources users.

According to Tantawy et al. (2007) and Sisay et al. (2017), several methodologies have been established to prepare for the allocation and distribution of irrigation

Natural System

Human System

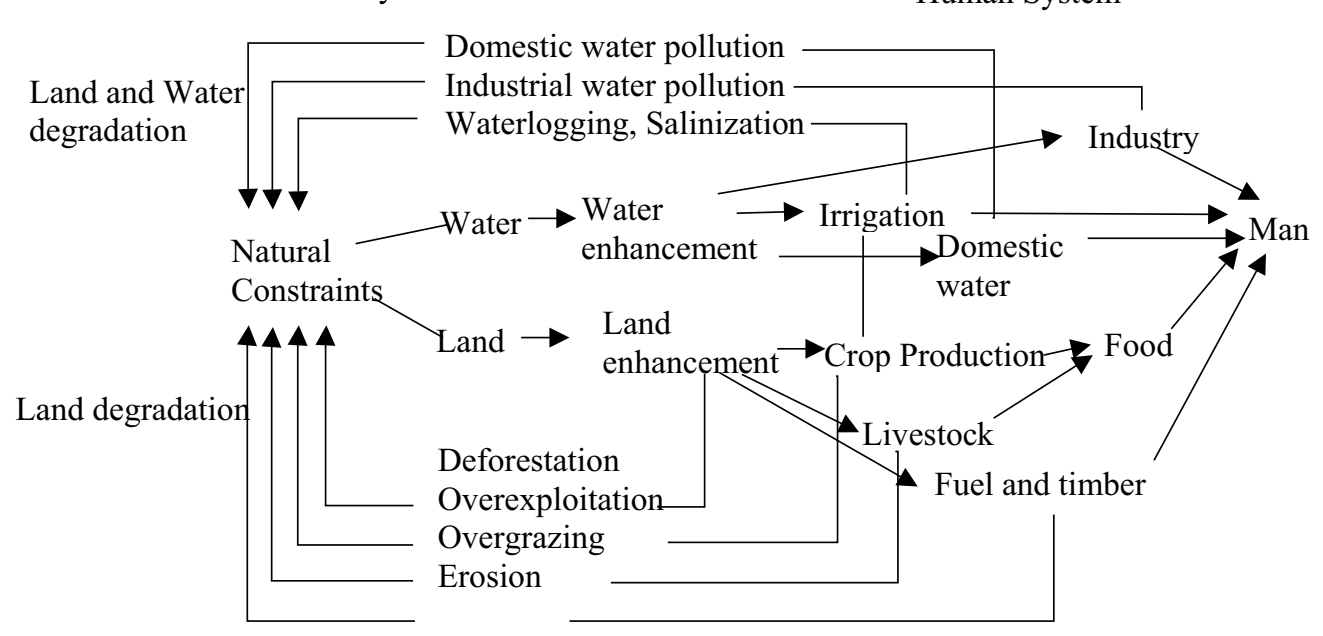

Fig. 1 Complex nature of interactions and feedbacks between the natural and human system (After Falkenmark 1986a, b) 


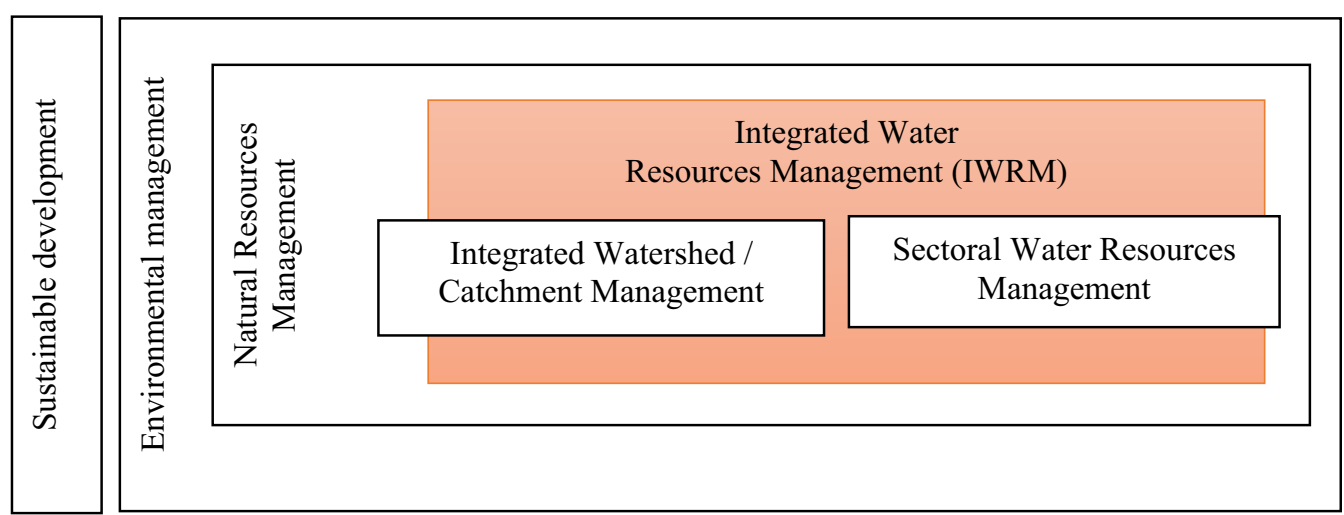

Fig. 2 Integrated water resources management and sustainable development (After Jouravlev and Chávez 2002)

water during the planning and management process. The objectives of allocation and distribution plans is to optimize the uses of water and hence land resources. In these methods, to obtain optimum benefit from irrigated agriculture, the water and land resources were optimized. Even though the distribution models were mostly concerned with enhancing the productivity of agriculture from irrigation projects, it did not give attention issues related to water distribution for all communities found within the watershed particularly at the time of limited water available.

Awulachew et al. (2005), made a study for Ethiopia stated that due to poor and unsustainable water harvesting and management in all parts of the country, agricultural productivity is vulnerable to rainfall variability, consequently illustrates itself in the form of extended dry periods and persisted droughts. In addition to that, related to inefficient water management in the country empirical evidences have identified. For example, Girma and Seleshi (2007), identified inefficient management and low performance of some irrigation projects from Awash and Blue Nile basin; Checkol and Alamirew (2008), explained poor water management and inefficient water utilization at the Geray irrigation project in the Northern part of Ethiopia. However, Awulachew et al. (2005) recommended sustainable water harvesting and management and efficient use of water resource for agriculture could offer opportunities in order to handle the impact of climatic variability therefore improved crop productivity.

\section{Integrated water resources management -as demand driven approach}

Integrated water resources management is considered as a key component in which all relevant natural resources issues (land and water resources) are taken into consideration, the concerned parties along with specific socio-economic as well as environmental issues integrated together, with sustainability of integrated natural resources management. The key assumption of IWRM approach, which formulate the foundation for sustainable development is the basis for multi-disciplinary groups at various levels (i.e. local level, regional level, national and international level) in order to discuss on various issues related to conservation, efficient use and management of natural resources (water, land resources and ecosystems) (Fig. 3).

In the context of sustainable development, integrated water resources management, environmental management and natural resources have significant contribution (Fig. 3). The assumption of sustainable development includes of various components like environmental, economic and social components.

\section{Irrigation water use and management: a watershed perspective}

The watershed of a certain catchment integrates the downstream with the upstream in the form of water flowing as a part of the overall hydrological cycle of the watershed. The concern of upstream parts of the watershed are increasing the returns of agriculture productivity and other benefit. Communities obtaining their benefit from water diversion, over cultivation and expansion of agriculture into marginal land from the upstream parts of the watershed are now worried about resulting consequence to the downstream resources availability. However, over exploitation of natural resources in the upstream parts of the watershed negatively contribute for the downstream. Even though increasing the benefit and productivity for the whole catchment in a certain watershed, requires assessment of resource demand as well as equitable share of available resources in a rational watershed perspective. Besides this, allocation of available resource needs participatory planning and management that consider the 


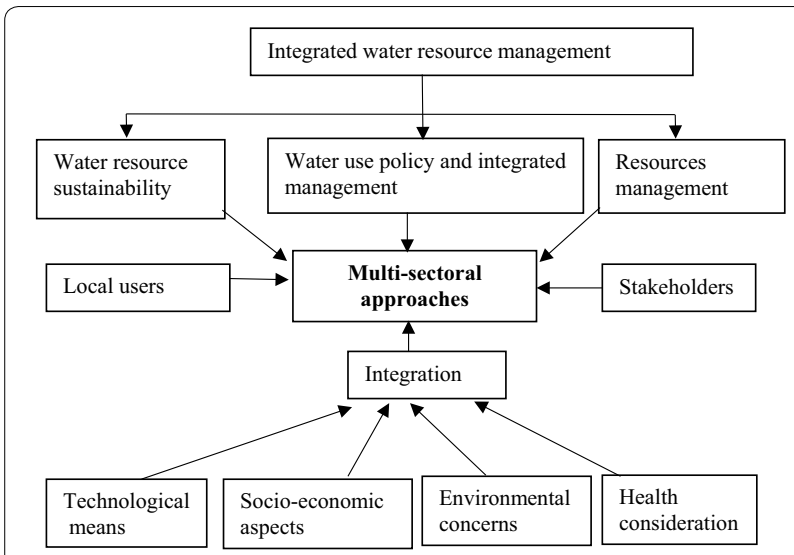

Fig. 3 Integrated waters resources management flow chart (After Al Radif 1999)

involvement of concerned stakeholders in the watershed. In determining the benefit of upstream water availability to the downstream farming system is the basic problems in which the watershed planners are facing. Likewise, it is difficult to determine how the availability of these resources might change over time as the upstream users consume more resource. Therefore, the benefit obtained from irrigated agriculture in the watershed can increase through minimizing the amount of available water used and optimizing the timing of water application for crops in the form of irrigation scheduling based on crop water requirement (Reca et al. Reca et al. 2001; Duan et al. 2004; Letcher and Jakeman 2003; Pingale et al. 2009, 2014; Worku and Tripahti 2015; Meshesha and Tripathi 2016). To reduce pressure of water shortage therefore conservation planning and water management at watershed level is critical (Worku et al. Worku et al. 2017a). Likewise, natural resources conservation management practices is helpful for the communities to determine the optimal amount of water resources consumption at the irrigation fields is therefore a key issue. As a result, there is a need to do more jobs related to water harvesting and management on the one hand and optimize the benefit form agriculture on other hand. Without enhancing the efficiency of water use, continuous and over exploitation of natural resource may result for conflicting interest among users within the watershed and between watersheds. Hence, the main objectives of this paper is to compute crop water requirements of major crops, describe the possibilities and opportunities of water harvesting and implementing integrated water resources management. The results presented are based on the findings of author's results and numerous empirical lessons from relevant literatures.

\section{Methods used}

\section{Study area}

The area, Beressa watershed, is located in the central highlands of Ethiopia. The watershed is drained by the headwaters of the Beressa River and it is one of the tributaries that forms part of upper Blue Nile basin. Situated at $9^{\circ} 34^{\prime}$ and $9^{\circ} 42^{\prime}$ north latitude and $39^{\circ} 30^{\prime}$ and $39^{\circ} 45^{\prime}$ eastern longitude (Fig. 4).

For this research, Beressa watershed has selected as case study because it represents the catchments where there is high competition over resources use. Additionally, the watershed can be considered as representative of the catchment of high landscape and various climatic zone varied within short distances. Alarming rate of population growth natural resources system use coupled with significant human interventions in many parts of the watershed makes it reasonable for LU/LC, climatic variability and natural resources management effect analysis on the hydrological regime of the catchment.

The topography of the study area lies at relatively high altitude ranges from 2747 to $3674 \mathrm{~m}$ above sea level, in a zone, which is a part of central plateau of the country. The physiographic characteristics of the area is mixed with steep-sided gullies, plateaus, hills and river gorges. There are very few information available related to geological formation of Beressa watershed. Accordingly, the geological formation of the area is used to define the watershed characteristic. The geology of the country general encompasses a mixture of the ancient crystalline basement rocks and volcanic rocks. The climatic condition of Ethiopia is largely influenced by changes of inter tropical convergence zone, sub-tropical pressure cells and the governance of Indian monsoon throughout the year. The two main air streams reason for dry and rainy seasons: in the late June to early September, in which inter tropical convergence zone is northernmost, hence the equator prevail air stream direction is southeast in southern parts of Ethiopia and south west in the central to the northern Ethiopia. These moist and warm winds are is results in high evaporation and water vapour saturation of the air mass for both above Atlantic and Indian Ocean respectively. In most parts of the country, the annual rainfall follows a bimodal distribution and the annual pattern of the country is normally distinguished as main rain season (Kiremit season) covers June to September; Bega season known by dry condition covers October to February; and Belg season manifested by small rain (March to May).

Since ancient times based on elevation, Ethiopians have divided their climate into five different zones. Each zone has its own rainfall pattern as well as farming system. Generally, the highland zone encompassing Dega and Wiena Dega zones, in which crop production is 


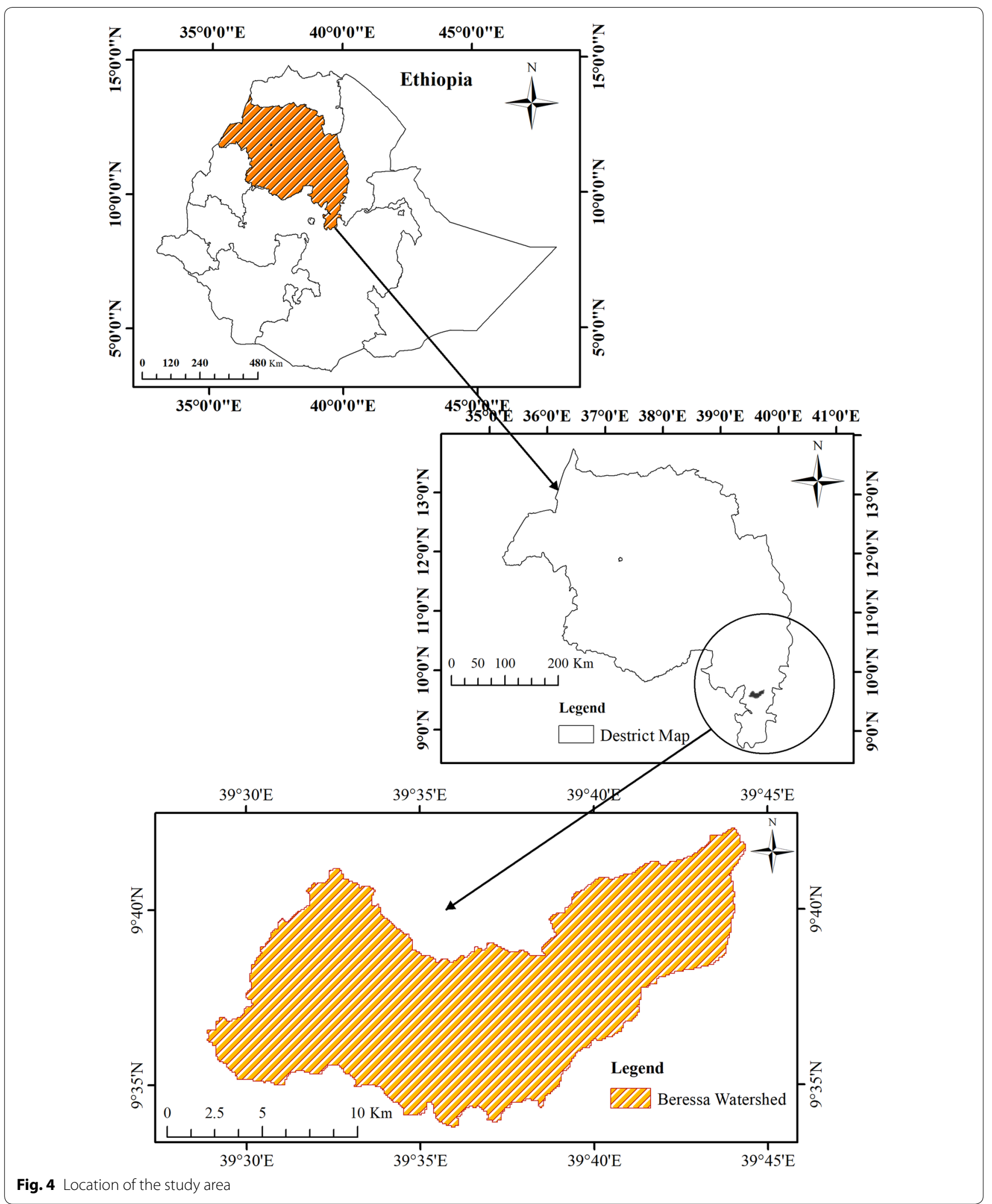


commonly prominent, whereas semi-arid as well as arid lowland zone commonly known as Kolla and Bereha mostly known by livestock in agro-pastoral and pastoral production systems.

\section{CROPWAT8.0 model}

The reference evapotranspiration (Eto) of individual different crops obtained by FAO Penman-Monteith methods, using the decision support system software known as CROPWAT8.0 model, which was developed by FAO. The program incorporates the process for reference crop evapotranspiration as well as crop water requirement as the same time used to allow in order to simulate crop water use under various conditions (i.e. crop, climate and soil) (FAO 2009).

In this study, Penman Monteinth methods has been applied and obtained using the following equation:

$$
E t_{o}=\frac{0.408 \Delta(R N-G)+\gamma\left(\frac{900}{T+273}\right) U 2(e s-e a)}{\Delta+\gamma(1+0.34 u 2)}
$$

where, $\mathrm{Et}_{\mathrm{O}}$ is the reference evapotranspiration ( $\mathrm{mm} /$ day), $\mathrm{T}$ is the mean Daily air temperature $\left({ }^{\circ} \mathrm{C}\right), \mathrm{Rn}$ is net radiation at the crop surface (MJ m-2 day-1), G is soil heat flux density (MIm-2 day-1), es is saturation vapour pressure $(\mathrm{kPa})$, ea is actual vapour pressure $(\mathrm{kPa}), \Delta$ is slope vapour pressure curve $\left(\mathrm{kPa}{ }^{\circ} \mathrm{C}-1\right), \gamma$ is psychrometric constant $\left(\mathrm{kPa}{ }^{\circ} \mathrm{C}-1\right)$.

Crop water requirements/season $(\mathrm{CWR} / \mathrm{mm})$ obtained for different crops. It used to define as the depth of water, which is needed to satisfy the loss of water through evapotranspiration of crops, growing in the farm filed under in a condition of non-restricting soil including fertility and soil water and hence obtaining maximum production potential in a certain growing environment (Doorenbos and Pruitt 1977). Crop water requirement obtained using the following equation:

$$
C W R=\sum E t_{c}=\sum\left(K_{c} * E t_{o}\right)
$$

where, $\mathrm{Kc}$ is the crop coefficient at different growth stages of crops, Eto $(\mathrm{mm})$ is reference evapotranspiration, which is reported by FAO, $\mathrm{Et}_{\mathrm{c}}$ is the specific evapotranspiration.

The meteorological data like temperature $\left({ }^{\circ} \mathrm{C}\right)$, relative humidity (\%), sunshine (h) and wind speed ( $\mathrm{km} /$ day) has been used for this study.

The major crops of the area are bean, wheat, barely, lentils, chickpea and garlic. The value of crop coefficient (Kc) are taken from FAO. Crop coefficient $(\mathrm{Kc})$ values for initial, development, mid and late growth stages of annual and seasonal crops are used.
The net irrigation requirement has been obtained for the specific cropping periods, it is the difference between a certain crop evapotranspiration (Etc) in a certain conditions and effective rainfall. It is obtained using the following equation:

$$
N I R=E T_{c}-E R-G E
$$

where, NIR is net irrigation requirement, Etc is crop evapotranspiration, ER is effective rainfall, $G e$ is the groundwater contribution from the water table (however, it is not considered in the calculation as it has not significant contribution so it is negligible).

In order to recognize the potential contribution of rainwater availability for cultivation, Rainfall Contribution Index (RCI) has obtained by the following techniques:

$$
R C I=\sum_{i=1}^{n} \frac{E r_{i}}{\frac{E t c_{i}}{n}}
$$

where Er is effective rainfall in mm; Etc is crop water requirement in $\mathrm{mm}$; $\mathrm{n}$ is the total time step for the growing periods and $\mathrm{i}$ is the time step; the highest $\mathrm{RCI}(\sim 1)$ rainfall is sufficient for crop growth; whereas lower RCI values indicates rainfall is insufficient for crop growth. Crop water requirement of crops can obtained by Eq. 2 .

The volume of effective precipitation in which used to represent the portion of total amount of precipitation in which plants are used to satisfy crop water requirement (consumptive use of water) has been found by the United State Department of Agriculture soil conservation methods (USDA) using the following equation:

$$
\begin{array}{ll}
E r=\frac{125-0.2 P_{t o t}}{125} & \text { for } P_{t o t}<250 \mathrm{~mm} \\
E r=125+0.1 P_{t o t} & \text { for } P_{t o t}>250 \mathrm{~mm}
\end{array}
$$

where, Er is the volume of effective precipitation $(\mathrm{mm})$ and $\mathrm{P}_{t o t}$ is the total precipitation $(\mathrm{mm})$.

\section{Results and discussion}

In the present study, estimation of crop water requirements in the study area for seven major crops was undertaken. Notwithstanding the fact that most of the agricultural practices in Ethiopia is rainfed, attempt has been made to assess crop's irrigation water requirements. The following are discussion of this study for each crops using CROPWAT8.0 model results.

The crop irrigation and water requirement were simulated for each growth periods in various climatic conditions per each cropping seasons in order to quantify the amount of water consumed and needed to sustain crops growth for better production without and with the occurrence of rainfall. 
As can be seen from Fig. 5 the irrigation requirement of crops is highly variable among different crop per season. Bean, chickpea and lentil crops are among the lowest irrigation water requirement in the area accounted for 4.4, 5.2 and $85.3 \mathrm{~mm} /$ season respectively. This is due to the cropping calendar for these crops, in which the planting date during the main rainy season (June to September) which is significantly contribute for lower irrigation water requirement.

On the other hand, barley, wheat, potato and garlic crops are among the common crops during less rainy season extended from February to June therefore those crops are among the highest irrigation requirements with the values of $255.9,205.4,274.6$ and $246.7 \mathrm{~mm}$ /season respectively. Similarly, the highest crop water requirements has also been observed in each cropping season. As can observed from Figs. 6 and 7; and Table 1 during the month of January to June there is relatively high potential evapotranspiration. Similarly, during these months higher temperature has observed which has considerably contributed for high crop water requirement.

During small rainy season, since crops evapotranspiration is high due to high temperature; therefore, the crop water requirement is relatively high as compared to rainy season. This indicates that the crops growers during small rainy season has been discouraged and the same experience will be continuing not to grow the crops as the irrigation and water requirement of crops will increase and likely to result in more strong competition for water sharing among local users. The major crop characteristics collected for this study along with FAO reference has been summarized in Table 2. Therefore, due to this highly inconsistent temporal and spatial variability of rainfall occurring over the entire growing season, there is a need for supplemental irrigation using rainwater harvesting even in the wet and rainy season for better production.

Rainfall Contribution Index (RCI) for each crops from different planting dates has been already shown in Fig. 5 .

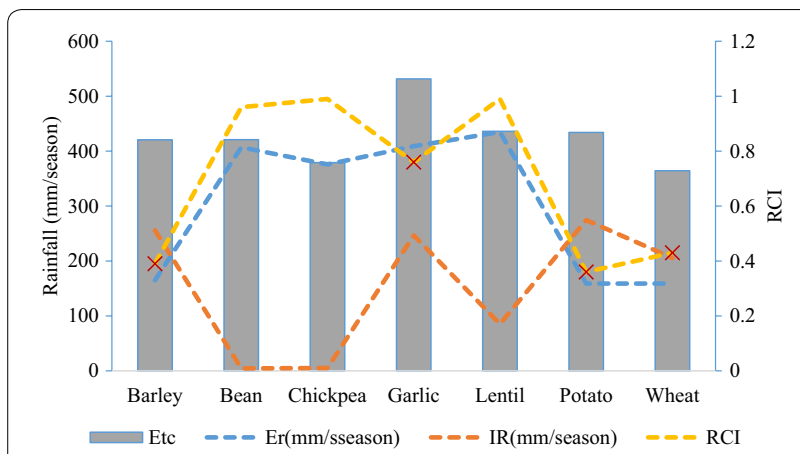

Fig. 5 Crop water and Irrigation Requirements. Etc is Crop evapotranspiration; Er is Effective rainfall; IR is Irrigation requirement; $\mathrm{RCl}$ is Rainfall Contribution Index. ${ }^{\mathrm{X}}$ Effective rainfall is insufficient in all growth stages (needs supplemental irrigation)
According to Wang et al. (2008), the highest value ( 1) of RCI indicates the amount of effective rainfall is sufficient for crop growth in a cropping season, while the smaller Rainfall Contribution Index/RCI/value reflects the available rainwater is insufficient for the whole crop growth stage. Therefore, for the crops sown during small rainy season (barley, Garlic, potato and wheat) based on the value of RCI, the availability of effective rainfall is insufficient to satisfy the full growth stages of crop water requirement. Therefore, there is a need for supplemental irrigation practice and rainwater harvesting and a necessity for integrated water resources management particularly during small rainy season in which during high water requirement periods.

\section{Water harvesting for IWRM—a mean for stabilizing food shortage \\ Existing scenarios}

As the same authors have done early, currently communities in the Beressa watershed is challenging with numerous interrelated difficulties. In the earlier studies, authors have observed there is rising need for additional production and income in order to cope with alarming rate of population growth with fixed and limited natural resource available in the area (Meshesha, et al. 2016; Worku et al. 2017a). Generally, some of the

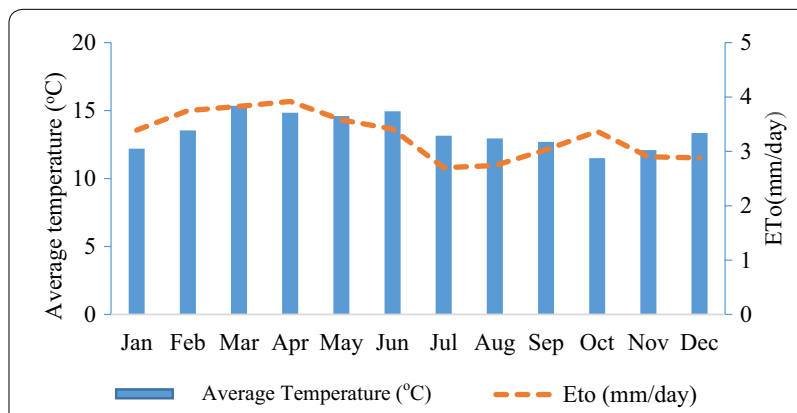

Fig. 6 Mean monthly temperature and evapotranspiration

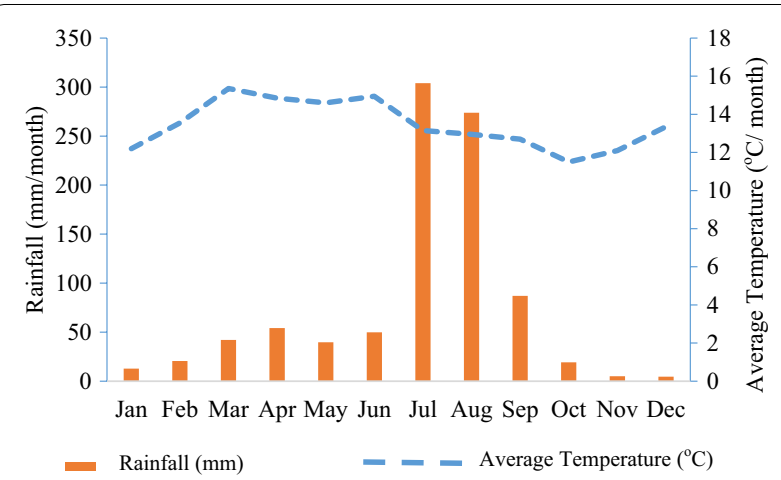

Fig. 7 Patterns of Rainfall and temperature in the area 
Table 1 Monthly reference evapotranspiration (Eto)

\begin{tabular}{|c|c|c|c|c|c|c|c|}
\hline Month & Min temp. $\left({ }^{\circ} \mathrm{C}\right)$ & Max temp. $\left({ }^{\circ} \mathrm{C}\right)$ & $\begin{array}{l}\text { Relative } \\
\text { humidity (\%) }\end{array}$ & $\begin{array}{l}\text { Wind speed } \\
(\mathrm{km} / \text { day })\end{array}$ & Sun (h) & $\begin{array}{l}\operatorname{Rad}\left(\mathrm{MJ} / \mathrm{m}^{2} /\right. \\
\text { day) }\end{array}$ & Eto (mm/day) \\
\hline January & 3.6 & 20.8 & 80 & 72 & 10.1 & 22.2 & 3.39 \\
\hline February & 5.2 & 21.9 & 70 & 73 & 9.6 & 22.8 & 3.75 \\
\hline March & 8.6 & 22.1 & 83 & 85 & 8.4 & 22.2 & 3.83 \\
\hline April & 7.5 & 22.2 & 92 & 70 & 8.6 & 22.8 & 3.92 \\
\hline May & 7.2 & 22.0 & 85 & 74 & 7.3 & 20.3 & 3.58 \\
\hline June & 7.9 & 22.0 & 84 & 70 & 6.6 & 18.9 & 3.41 \\
\hline July & 8.7 & 17.6 & 95 & 73 & 4.5 & 15.9 & 2.70 \\
\hline August & 8.5 & 17.4 & 95 & 58 & 4.5 & 16.2 & 2.74 \\
\hline September & 6.3 & 19.1 & 95 & 59 & 5.7 & 18.0 & 3.03 \\
\hline October & 4.2 & 18.8 & 92 & 55 & 8.6 & 21.6 & 3.37 \\
\hline November & 3.7 & 19.0 & 88 & 81 & 7.3 & 18.4 & 2.90 \\
\hline December & 1.3 & 19.1 & 83 & 80 & 8.2 & 19.0 & 2.88 \\
\hline Average & 6.1 & 20.2 & 87 & 71 & 7.5 & 19.9 & 3.29 \\
\hline
\end{tabular}

Table 2 Crop characteristics data for model inputs

\begin{tabular}{|c|c|c|c|c|c|c|c|c|c|c|}
\hline \multirow[t]{2}{*}{ SNo. } & \multirow[t]{2}{*}{ Crop type } & \multicolumn{2}{|c|}{ Initial stage } & \multicolumn{2}{|c|}{ Dev't stages } & \multicolumn{2}{|c|}{ Mid-Season } & \multicolumn{2}{|c|}{ Late-season } & \multirow[t]{2}{*}{ Crop height (m) } \\
\hline & & (Days) & $\mathrm{Kc}$ & (Days) & Kc & (Days) & $\mathrm{Kc}$ & (Days) & $\mathrm{Kc}$ & \\
\hline 1 & Barley & 20 & 0.3 & 25 & 1.15 & 60 & 1.13 & 30 & 0.25 & 1.00 \\
\hline 2 & Bean & 20 & 0.40 & 30 & 1.15 & 40 & 1.1 & 20 & 0.35 & 0.60 \\
\hline 3 & Chickpea & 15 & 0.50 & 25 & 1.15 & 35 & 1.09 & 15 & 1.10 & 0.50 \\
\hline 4 & Garlic & 30 & 0.70 & 55 & 1.00 & 55 & 0.99 & 40 & 0.70 & 0.30 \\
\hline 5 & Lentil & 20 & 0.40 & 30 & 1.00 & 60 & 0.958 & 40 & 0.3 & 0.50 \\
\hline 6 & Potato & 25 & 0.50 & 30 & 1.15 & 45 & 1.14 & 30 & 0.75 & 0.60 \\
\hline 7 & Wheat & 30 & 0.30 & 30 & 1.15 & 40 & 1.125 & 30 & 0.30 & 1.00 \\
\hline
\end{tabular}

most pressing problems that affect efficient and sustainable production for the area includes:

- Rainfall variability,

- Removal of forest and therefore soil erosion particularly on the upland areas hence flood event for the lower areas,

- Fragmented land holding and therefore expansion of farming into sloping and marginal land,

- Dependant of dunk cake as household biofuel consumption, therefore low level of, and generally declining, the status of soil fertility conditions,

- Inadequate and insufficient access to off farm income and therefore high pressure on land resources and other natural resources,

- Weak and unsustainable water harvesting and management practices and,

- Lack of site-specific soil and water conservation management practices.
These aggravating problems specify the degree to which the communities are confined in a multifaceted web of environmental challenges. Therefore, the condition becomes serious to the subsistence in which the susceptibility to risk is so enormous. However, controlling and reducing the aggravating problems not only depends on local level actions by the community, but also needs the integration of all the stakeholders at various levels of decision- making process.

\section{Towards water harvesting: a relief to rainfall variability}

The erratic nature of rainfall pattern particularly during the dry season has been the bottleneck for food production and this further exacerbated by climatic change in which expected to manifested in the form of rainfall variability (Dourojeanni 2001; Hooper 2006; Oweis and Hachum 2006; Meshesha, et al. 2016). As can be seen from Fig. 8 the distribution of annual temperature is increasing while the mean annual temperature shows increasing. 
The intensity of precipitation during rainy season can often be higher (Fig. 7) than the rate of infiltration and water holding capacity of the soil, which is a cause for excess surface runoff, erosion and degradation hence high sediment generation that has experienced in the area (Fig. 9). In many parts of Ethiopia where rainfall intensity and variability are high, unpredictability and further decline of normal rainfall is also expected due to global warming.

Therefore, rainwater harvesting and integrated water resources management is gaining importance and drought power as a supplement to irrigation and other benefit (Ngigi 2009). Water harvesting is a collection and concentration of runoff in order to support agriculture, livestock watering, pastureland, fodder, tree production and domestic use in the area of erratic and variable rainfall. It is the aim of reducing the pressure of temporal and spatial rainfall shortage to satisfy household and productive use. In agricultural production systems, water harvesting is composed of an area of runoff producing is known as catchment area and utilization of runoff area is also known as cropped basin. In-situ water harvesting, internal catchment water harvesting (micro catchment) and external catchment (macro catchment) water harvesting are some of the major categories of water harvesting according to distance catchment area and cropped basin (Oweis and Hachum 2006). Water harvesting systems are categorize into two main types: in situ water conservation and management practices, small basins, bunds, and runoff based systems (Fig. 10).

The in situ water harvesting also known as soil and water conservation practices, in which the method is used to increase the amount of stored water in the soil profile. It includes small movements of rainwater as a surface runoff to arrest the water where and when it is demanded most. For agricultural purpose, it is achieved in different ways such as conservation farming, conservation tillage and conventional tillage. It is an efficient and effective strategy in order to manage excess floods in the in situ and ex situ, especially in the highland parts of

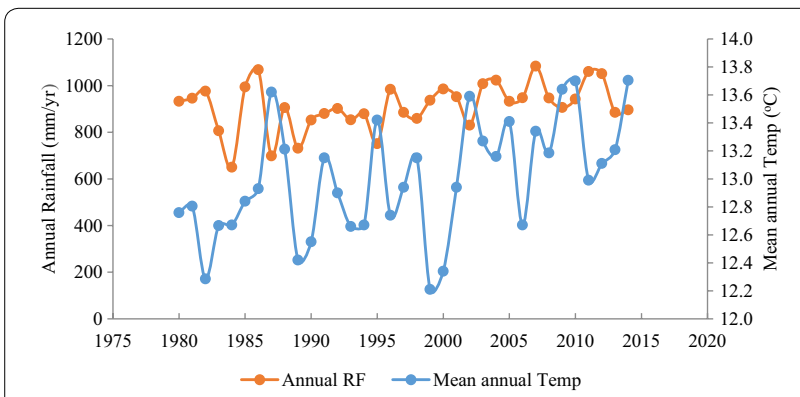

Fig. 8 Annual rainfall and temperature variability

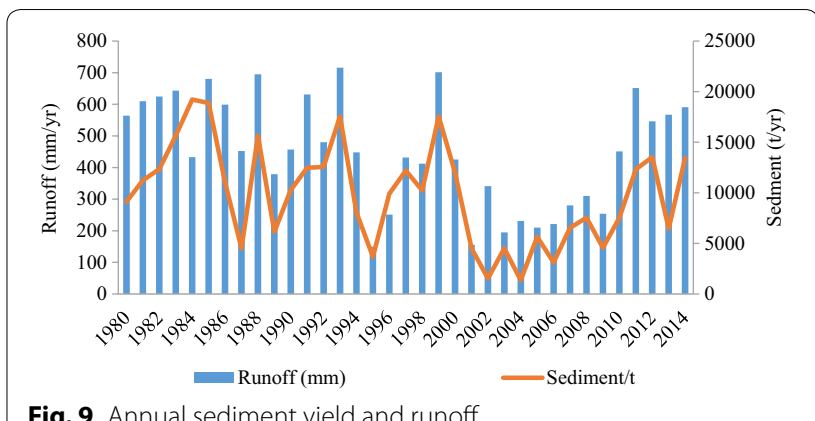

Fig. 9 Annual sediment yield and runoff

Ethiopia. Hence, water harvesting possibly satisfy water needs during dry spells and create additional access for multiple water uses. According to De Fraiture and Wichelns (2010), estimation 78\% of water consumed by agriculture originated from rainfall. Miro-catchment water harvesting is most widely used techniques of water harvesting in the form of contour ridges (with an interval of 5 to $20 \mathrm{~m}$ between contours), soil and stone bunds (trapezoidal and semi-circular bunds). Percolation pits (digging holes usually 5 to $20 \mathrm{~cm}$ deep), and small runoff basins (with an optimal dimension of 5 to $10 \mathrm{~m}$ wide by 10 to $25 \mathrm{~m}$ long) are some of the prominent techniques of water harvesting techniques applied for rainfed area for the sustainability of agriculture (Oweis and Hachum 2006). In order to supplement for the regeneration as well as plantation of forages, trees and grasses particularly on medium slopes to high slopes contour ridges has substantial contribution. To overwhelm the difficulties of contouring, semi-circular as well as trapezoidal bunds are typically used. The shape of the bund in the form of semi-circular or trapezoid facing (fronting) directly upslope are formed at a spacing, which allows adequate catchments to provide vital runoff water, which collects in the bund, therefore plants are growing. According to Oweis and Hachum (2006), the diameter between the

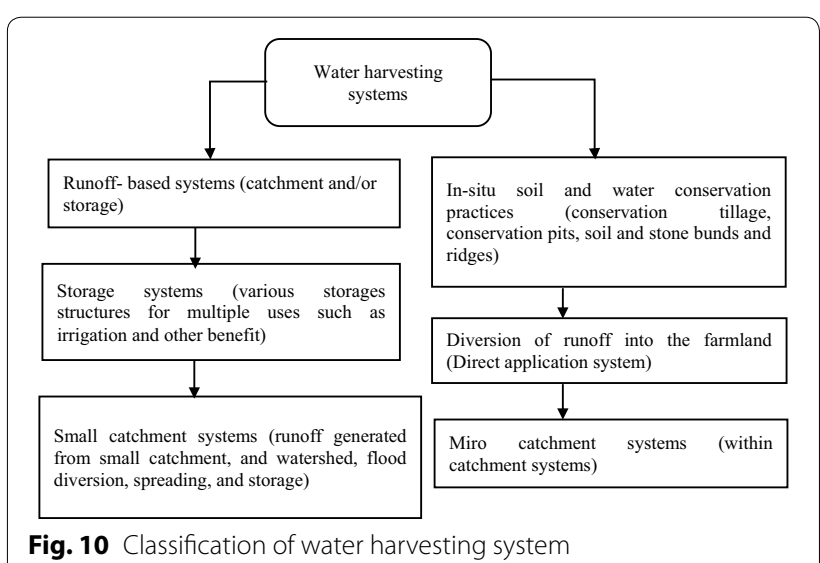


two consecutive ends of the bunds ranged between 1 and $8 \mathrm{~m}$ with 35 to $50 \mathrm{~cm}$ high, therefore the water (runoff) captured here and can store into the plant root zone. The principle of designing micro-catchment water harvesting in order to concentrate water from rainfall, runoff and other source, it involves a catchment area and cultivated area, which receives and then concentrate water from the given catchment area for agricultural supply and other benefit. In terms of size association between catchment and cultivated area is a determined by rainfall and available runoff (Fig. 7). Therefore, to make system effective and efficient in a sustainable way it is better to obtain the ratio between catchment and cultivated area if the data, which is related to rainfall, runoff and crop water demand, is available (Moges 2004). Therefore, the ration between the two is determined by the following equation:

$$
\frac{c a t}{c u}=\frac{C W R-D R}{D R * k * e f}
$$

NB: cat is catchment area, cu is cultivated area, CWR is crop water requirement, DR is design rainfall, $\mathrm{k}$ is runoff coefficient and ef is efficiency factor.

The value for crop water requirement already obtained by Eq. 2 .

Where, Design rainfall is total amount of rainfall during the cropping season, if the actual rainfall is during the cropping season is less than the design rainfall, there will be moisture stress in the crops; if the design rainfall is less than actual rainfall there will be surplus runoff and cause for erosion and degradation. The rainfall depth that is assigned to a chance of occurrence or exceedance is denoted as the design rainfall. This parameter is one of the input parameters used to design a model for determining the ratio of catchment area to cultivated areas. The value is obtained by means of a statistical probability analysis using the following equation (Plotting position formula):

$$
P(\%)=\frac{m=0.375}{N+0.25} * 100
$$

where, $\mathrm{N}$ is year of observation, which is used to obtain the total annual amount of rainfall for the cropping season. The value of total rainfall ranked from the largest $(\mathrm{m}=1)$ to the lowest $(\mathrm{m}=\mathrm{x})$ and $\mathrm{P}(\%)$ is the probability of occurrence.

The design rainfall is based on higher probability, which refers to the lesser design rainfall thus the system is more reliable and efficient. Therefore, the concentrated water can satisfy the water requirement of crops per cropping season. However, the probability of frequent flooding occurrence may affect the system efficiency particularly when rainfall surpass the design rainfall unless proper care should take into consider. Runoff coefficient is the share of total rainfall, which is flowing as surface runoff. It is relied on vegetation cover, slope degree, rainfall duration, soil type, soil moisture and rainfall duration. The value of runoff coefficient ranges between 0.1 and 0.5 , which is obtained by the following techniques:

$$
K=\frac{\text { Yearly (seasonally) total runoff }(\mathrm{mm})}{\text { Yearly (seasonally) total rainfall }(\mathrm{mm})}
$$

The efficiency factor is used to measure whether the system is efficient or not. When the area is level as well as smooth the efficiency of the system is more effective. The value of efficiency factor is ranges from 0.5 to 0.75 . For the Beressa watershed the runoff coefficient, efficiency factor, and design rainfall with the probability of $52.84 \%$ are $0.48,0.5$, and $931.4 \mathrm{~mm}$ respectively. Therefore, based on the available data catchment area: cultivated area have been drown as of knowing this ratio is useful for water harvesting in which crops area intended to grow.

Crop water requirements for all crops already presented in Fig. 7. The catchment area for barley and bean must be 2.28 times larger than the cultivated area, which means the catchment: cultivated area ratio is 2.2:1. As the ratio between the two is moderate the system can be designed to harvest water with the assumption of low runoff coefficient. For garlic, the area of catchment should be approximately 2 (1.8) times higher than the cultivated area. For micro catchment system, the ratio are always lower due to the higher efficiency of water use as well as higher runoff coefficient. Using a design rainfall of with the probability value of $52.84 \%$ with the ratio of 1.8:1. In general, the sketch of water harvesting process in a micro watershed has shown in Fig. 11.

\section{Optimization of supplemental irrigation}

In the area during the last 35 years, based on the author's observations, the distribution and pattern of rainfall could be classified as uneven, irregular and erratic. Therefore, has considerable contribution to low crop production, food shortage and insecurity (Worku et al. 2017b). Therefore, depending on the historical trend of rainfall variability and prolonged increase of surface temperature, optimization of supplemental irrigation from harvested water would be useful during excess rainfall and runoff when rainfall is over. The following three important points are taken into consideration while optimizing supplemental irrigation for rainfed agriculture.

1. Since rainfall is the main source of water for agriculture and other purpose, supplemental irrigation applied when the amount of rainfall is insufficient to satisfy crop water demand and stable crop production during the growing season,

2. Water is essential to rainfed agriculture, which is used for production without irrigation, 


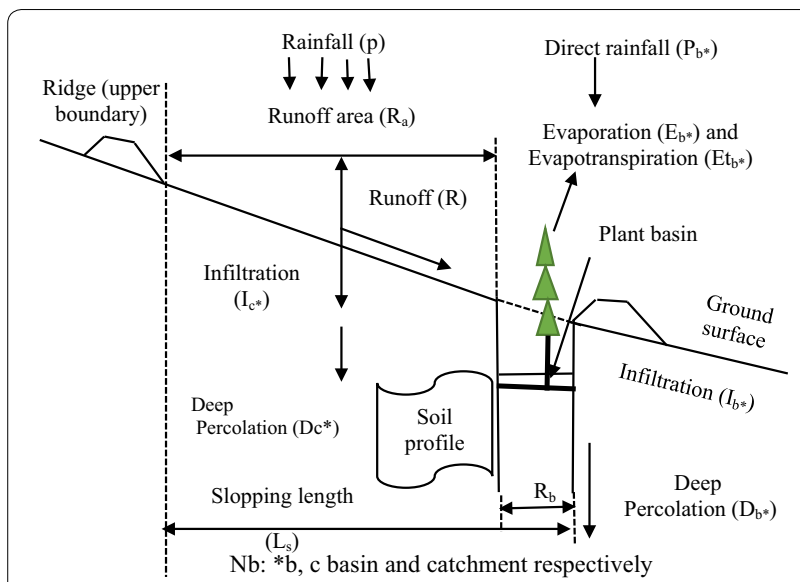

Fig. 11 Sketch of water harvesting process in a micro catchment (After Ali et al. 2010)

3. The volume and techniques of supplemental irrigation are planned not only to apply moisture stressfree situations during the whole crop growing season, but also it is to secure a minimum volume of water accessible during the critical periods of crop growth that would allow optimal instead of maximum production.

\section{Conclusions}

In the high land parts of the country, particularly during dry and less rainy season, in which water shortage is very high, land and other natural resource is fragile. Resources degradation, rainfall variability, inadequate and insufficient access to off-farm income and lack of site specific soil and water conservation practices are very high, therefore recurrent drought and food shortage can cause the most pressing hardship on the rainfed agriculture. Likewise, techniques and technologies of water harvesting during excess rainfall season coupled with fragmented approach to water resources management is the aggravating problems specifying the degree to which the communities are confined in a multifaceted web of environmental challenges. Therefore, the conditions becomes serious to the subsistence in which the susceptibility to risk is so enormous. As indicated from CROPWAT8.0 model results, the irrigation requirements of crops during dry and less rainy season is high. Similarly, the results of Rainfall Contribution Index (RCI value far from 1) confirmed that during less rainy season the availability of rainfall is insufficient to satisfy the crops water requirements for the whole crop growth stages. Therefore, farmers during such season has been discouraged and the same experience will be continuing not to grow the crops as the irrigation and water requirement of crops will increase and most likely to result in more strong competition for available water sharing among local users. Therefore, due to this highly inconsistent temporal and spatial variability of rainfall occurring over the entire growing season, there is a need for supplemental irrigation using rainwater harvesting even in the wet and rainy season for better production. Additionally, it can laid a foundation for water management approaches to reduce the adverse effects of food shortage in Ethiopia. Harvesting rainfall and surface runoff and using it in an integrated way can reduce intense pressure on crops therefore can reduce negative economic consequences in rural communities. Policies and concerned institutions are necessary to overwhelm the adverse problems. Therefore, it is essential that the concerned stockholders and communities should be involved in every phase of planning and implementing water harvesting process. Generally, integrated water resources management plays a significant role in order to integrate and address various aspects water shortage and sustainably use harvested water for supplemental irrigation during less rainfall and dry season.

\section{Abbreviations}

CROPWAT8.0: crop water requirements; $\mathrm{RCl}$ : rainfall contribution index; IWRM: integrated water resources management; t/yr: ton per a year; kc: crop coefficient; Eto: reference evapotranspiration; Etc: crop evapotranspiration; Er: effective rainfall.

\section{Authors' contributions}

In the acquisition of the data, data collection, data coding and entry, data analysis, interpretation of the result, and writing has been substantially contributed by TW and DK have been involved on critically advising, revising the manuscript and made possible suggestion. All authors read and approved the final manuscript

\section{Author details}

${ }^{1}$ Department of Water Resources and Irrigation Management, Debre Berhan University, P.o.BOX: 91, Addis Ababa, Ethiopia. ${ }^{2}$ Department of Water Resources Development and Management, Indian Institute of Technology Roorkee, Roorkee 24 667, India.

\section{Acknowledgements}

This research has supported by the Ministry of education, government of Ethiopia. Therefore, the authors acknowledge them. Sincere thanks also extended to all who took parts for the manuscript.

\section{Competing interests}

The authors declare that they have no competing interests.

\section{Availability of data and materials}

The data used in this paper is with the authors and can be available upon demand.

\section{Consent for publication}

Not applicable.

Ethics approval and consent to participate

Not applicable. 


\section{Funding}

This research was supported by Ministry of Education, Ethiopia.

\section{Publisher's Note}

Springer Nature remains neutral with regard to jurisdictional claims in published maps and institutional affiliations.

Received: 30 January 2019 Accepted: 12 February 2019

Published online: 22 February 2019

\section{References}

Al Radif A (1999) Integrated water resources management (IWRM): an approach to face the challenges of the next century and to avert future crises. Desalination 124(1-3):145-153

Ali A, Yazar A, Aal AA, Oweis T, Hayek P (2010) Micro-catchment water harvesting potential of an arid environment. Agric Water Manag 98(1):96-104

Awulachew SB, Merrey D, Kamara A, Van Koppen B, Penning de Vries F, Boelee E (2005). Experiences and opportunities for promoting small-scale/micro irrigation and rainwater harvesting for food security in Ethiopia, vol 98. IWMI

Checkol G, Alamirew T (2008) Technical and Institutional Evaluation of Geray Irrigation Scheme in West Gojjam zone, Amhara Region

De Fraiture C, Wichelns D (2010) Satisfying future water demands for agriculture. Agric Water Manag 97(4):502-511

Doorenbos J, Pruitt WO (1977) Guidelines for predicting crop water requirements. Irrig Drain Paper 24:18

Dourojeanni A (2001) Water management at the river basin level: challenges in Latin America. ECLAC

Duan Q, Gupta HV, Sorooshian S, Rousseau AN, Turcotte R (2004) Calibration of watershed models. American Geophysical Union

Falkenmark M (1986a) Fresh water: time for a modified approach. Ambio 1:192-200

Falkenmark M (1986b) Macro-scale water supply/demand comparison on the global scene. Beiträge zur Hydrologie 6:15-40

FAO (2009) Cropwat 8.0 for windows user guide. Rome, Italy

Girma MMA, Seleshi B (2007) Irrigation practices in Ethiopia: characteristics of selected irrigation schemes, vol 124. IWMI, New York

Gorantiwar SD, Smout IK (2005) Performance assessment of irrigation water management of heterogeneous irrigation schemes: 1. A framework for evaluation. Irrig Drain Syst 19(1):1-36

Gorantiwar SD, Smout IK, Vairavamoorthy K (2006) Performance-based optimization of land and water resources within irrigation schemes. I: method. J Irrig Drain Eng 132(4):332-340

Halefom A, Sisay E, Khare D, Singh L, Worku T (2017) Hydrological modeling of urban catchment using semi-distributed model. Model Earth Syst Environ 3(2):683-692

Hooper B (2006) Integrated river basin governance and key performance indicators. IWA Yearbook 2006:35-38

Jouravlev A, Chávez G (2002) Gestión del agua a nivel de cuencas: teoría y práctica, vol 1. United Nations Publications, New York

Letcher RA, Jakeman AJ (2003) Application of an adaptive method for integrated assessment of water allocation issues in the Namoi River Catchment, Australia. Int Assess 4(2):73-89

Loucks DP (2000) Sustainable water resources management. Water Int 25(1):3-10
Matondo II (2002) A comparison between conventional and integrated water resources planning and management. Phys Chem Earth 27(11):831-838 Meshesha TW, Tripathi SK (2016) Farmer's perception on soil erosion and land degradation problems and management practices in the Beressa Watershed of Ethiopia. J Water Resour Ocean Sci 5(5):64-72

Meshesha TW, Tripathi SK, Khare D (2016) Analyses of land use and land cover change dynamics using GIS and remote sensing during 1984 and 2015 in the Beressa Watershed Northern Central Highland of Ethiopia. Model Earth Syst Environ 2(4):168

Moges $Y$ (2004) Water harvesting techniques: training and construction manual. consultancy sub-report number 2. Tropical Forestry.

Molden D, Murray-Rust H, Sakthivadivel R, Makin I (2003) A water-productivity framework for understanding and action. Water Prod Agric 1:8

Ngigi SN (2009) Climate change adaptation strategies: water resources management options for smallholder farming systems in sub-Saharan Africa. The Earth Institute at Columbia University, New York, NY

Oweis T, Hachum A (2006) Water harvesting and supplemental irrigation for improved water productivity of dry farming systems in West Asia and North Africa. Agric Water Manag 80(1):57-73

Pingale SM, Khare D, Sharma HC, Jat MK (2009) Design of water harvesting structure based on supply and demand of water in a hilly watershed. J Environ Res Dev 3:3

Pingale SM, Jat MK, Khare D (2014) Integrated urban water management modelling under climate change scenarios. Resour Conserv Recycl 83:176-189

Reca J, Roldán J, Alcaide M, López R, Camacho E (2001) Optimisation model for water allocation in deficit irrigation systems: I. description of the model. Agric Water Manag 48(2):103-116

Simonovic SP (2000) A shared vision for management of water resources. Water Int 25(1):1-2

Sisay E, Halefom A, Khare D, Singh L, Worku T (2017) Hydrological modelling of ungauged urban watershed using SWAT model. Model Earth Syst Environ 3(2):693-702

Tantawy MM, Ouda SA, Khalil FA (2007) Irrigation optimization for different sesame varieties grown under water stress conditions. J App Sci Res 3(1):7-12

Wang YM, Traore S, Kerh T (2008) Computing and modelling for crop yields in Burkina Faso based on climatic data information. WSEAS Trans Inf Sci Appl 5(7):832-842

Worku T, Tripathi SK (2015) Watershed management in highlands of ethiopia: a review. Open Access Library J 2(06):1

Worku T, Khare D, Tripathi SK (2017a) Modelling runoff-sediment response to land use/land cover changes using integrated GIS and SWAT model in the Beressa watershed. Environ Earth Sci 76(16):550

Worku T, Tripathi SK, Khare D (2017b) Household level tree planting and its implication for environmental conservation in the Beressa Watershed of Ethiopia. Environ Syst Res 6(1):10

Worku T, Khare D, Tripathi SK (2018) Spatiotemporal trend analysis of rainfall and temperature, and its implication on crop production. J Water Climate Change 21:p.jwc2018064

Wurbs RA (1998) Dissemination of generalized water resources models in the United States. Water Int 23(3):190-198

\section{Submit your manuscript to a SpringerOpen ${ }^{\circ}$ journal and benefit from:}

- Convenient online submission

- Rigorous peer review

- Open access: articles freely available online

- High visibility within the field

- Retaining the copyright to your article

Submit your next manuscript at springeropen.com 